\title{
ギアニャール(バリ島・インドネシア)の都市空間構成に関する研究 一東南アジアに扔けるヒンドゥー都市の比較研究— \\ THE URBAN FORMATION OF GIANYAR IN BALI ISLAND, INDONESIA \\ - Comparative study on Hindu principle of urban formation in Southeast Asia-
}

山本直彦*, 布野修司**, 平尾和洋***, 川畑良彦****

Naohiko YAMAMOTO, Shuii FUNO, Kazuhiro HIRAO

and Yoshihiko KAWABATA

This paper analyses the influence of Balinese Hindu principle on the urban formation of Gianyar, one of the traditional towns founded in 18th century in Bali Island. Even though Balinese towns and villages have common house compounds as a fundamental unit, the structure of the settlements make several significant differences between towns and villages. In contrast with the linear composition of villages, urban structure of Gianyar rather has its focus in the center of the town. The analysis on caste distribution also illustrates the importance of the center. The emergence of urban blocks in Gianyar brought about several plot division patterns as opposed to the simple back-to-back plot division in the villages. However the analysis has revealed that the variety of plot division patterns in Gianyar is regulated by the sole principle i.e. the avoidance of building the gate for each house compound toward the north direction. The well-known Balinese cosmological concept of Nawasanga not only influences the planning of the house compound but also the urban formation.

\section{Keywords : Gianyar, Bali, Hinduism, Urban structure, Southeast Asia, Indonesia ギアニャール、バリ、ヒンドゥー教、都市構造、東南アジア、インドネシア}

1.はじめに

\section{1-1 研究の背景と目的}

筆者らは、これまでにインドネシア・バリ島のヒンドゥー藩王国 のひとつであったカランガセムKarangasamの植民都市として、隣接 するロンボク島に18世紀に建設されたチャクラヌガラCakranegara について研究を行ってきた。チャクラヌガラは、整然としたグリッ ドパターンによって街区が構成されている(図 1)!。計画都市とし て建設されたバリ・ヒンドゥーの理想都市と考えられる。本研究の 直接の動機は、いわば宗主国であるバリ島の都市形態の構成原理が、 チャクラヌガラの都市構成により純粋に現れているのではないかと いう仮説から出発している。

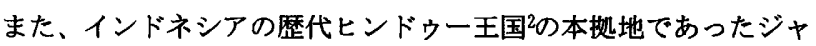
ワ島は、14世紀にイスラーム化の波に襲われる。イスラーム王国の 羁権の確立とともにジャワ島最後にして最大のヒンドゥー王国で

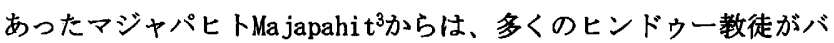
リ島へ逃れた(図 2)。かつてのマジャパヒトの王都トロウラン Trowulanは、廃墟と化し、現在、発掘作業が進みつつあるが依然と してその全貌は明らかではない。バリ島の藩王は、その正統性をマ ジャパヒトからの系譜に依拠するのが一般的であることを考えれば、 バリ島の都市形態は、ジャワ島における初期ヒンドゥ一都市の構成
について示唆を与えるものとも位置づけられる。 チャクラヌガラでは、マジャパヒト王国の宮廷叙事詩「ナーガラ クルターガマNagarakertagama」の写本が発見されている4。トロウ ランの王宮の叙述を含んだこの写本は、バリ島で数世紀の間保持さ れ続け、そしてロンボクまで伝えられているのである。14世紀から 18世紀にかけて、ジャワ島からバリ島へ、そしてロンボク島へとそ

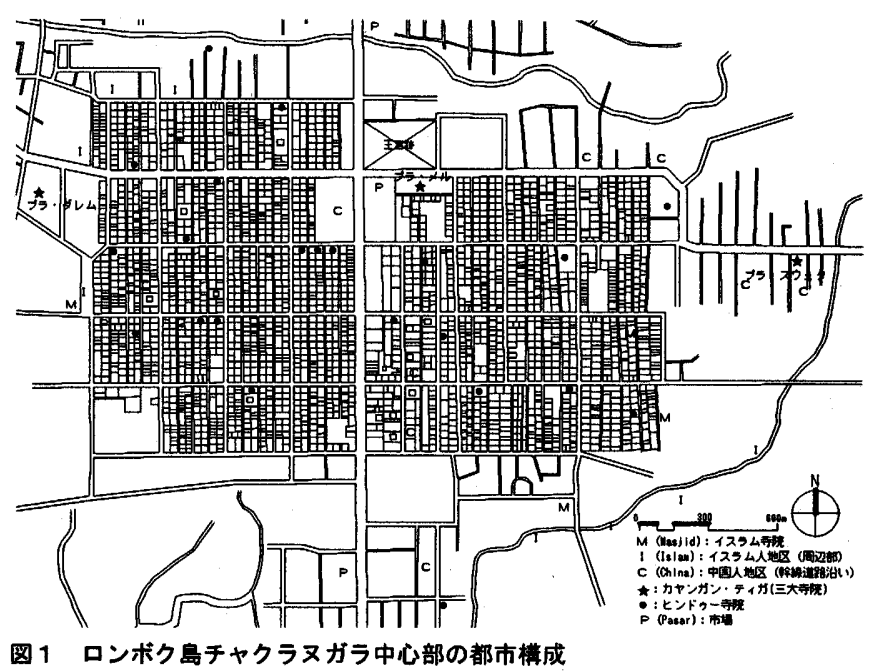

* 立命館大学理工学部建築都市デザイン学科 講師・博士 (工学)

** 京都大学大学院工学研究科建築学専攻 助教授. 工博

*** 立命館大学理工学部建築都市デザイン学科

***** 县教授・博士 (工学
Lecturer, Dept. of Architecture and Urban Design, Ritsumeikan Univ., Dr. Eng.

Assoc. Prof., Dept. of Architecture and Architectural Engineering, Graduate School of Engineering, Kyoto Univ., Dr. Eng.

Assoc. Prof., Dept. of Architecture and Urban Design, Ritsumeikan Univ., Dr. Eng. Matsushita Electric Works, Ltd., M. Eng. 
の支配版図を移動、拡大したインドネシアのヒンドゥー王権の都市 を考える場合に、バリ島は、地理的にも歷史的にも、その結節点と 考えられる。

他方、バリ島に関する既往研究については、「(20世紀の初頭のバ リ島の各藩王領の首都は、なかばヨーロッパ的、なかば中国的な商 業都市となっている。しかし、バリのほんとうの暮らしは何千もの 村や集落の中につまっているのだ。よコバルビアスが述べるように 5、その興味のほとんどが、人類学を始めとした様々な領域において 村落研究に集中している。後述するように建築学の分野からの既往 研究も、伝統的住居や村落構成に焦点をあてるものが大部分で、都 市研究は管見によればわずかに過ぎない。この意味で、本稿は、バ リ島の居住文化という枠組みに限っても、これまで扱われてこな かった都市研究に焦点を当てるという意義を持っている。

バリ島の伝統的住居は、山↔海（カジャkaja凡クロッkelod）と

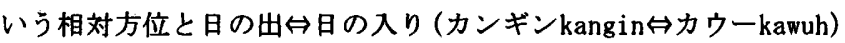
という絶対方位の空間ヒエラルキーが重層した $3 \times 3$ のマンダラ状 の構成をとるナワサンガNawasangaと呼ばれる空閒概念の上に成立 していることはよく知られる。

本稿の目的は、以上を背景として、バリ岛の村落と都市の構成の 違いを見る視点を、事例研究を通して提示した上で、こうしたバリ 島の独自の空間概念が、その都市構成にどのように影響しているの か明らかにすることである。さらに上述のように、チャクラヌガラ の都市構成を理解する上での示唆を得ることも視野に入れている。

バリ島は現在 8 県 (カプパテンKabupaten)に分かれている。この 区分はかつての潘王国の支配版図を継承したものであり、それぞれ の県庁所在都市が、かつての潘王国の支配中心であった王宮都市で ある。バリ島の中心的な王権は、南部を中心として歴史的に展開し てきた。この地域には、デンパサールDenpasar、タバナンTabanan、 ギアニャール、クルンクンKlungkun、バンリBangliの 5 つの都市が 存在する。一方、ヌガラNegara、シンガラジャSingaraja、カラン ガセムは地理的に、この中心的位置から䧺れている。これら 3 つの 都市は沿岸に位膡し交易都市としての性格が強く、トロウランや チャクラヌガラがそうであるように、通常、王宮都市は内陸部に位 置する特徽から外れている(図 3 )。バリ島南部の 5 つの都市のうち から、ギアニャールを選定した理由は、ギアニャールがその市域北 側に、王家の本貫村落バンBengを持っているためである。

ギアニャールとその本貫村落を始めとした周辺集落における現地 調査は、2003年7月 16 日〜9月 27 日の間に行った。主な調查内容は 以下のとおりである。。

·宅地割り、街路·路地、屋敷地出入り口向きの現状調査 ·寺院、王宫、集会施設等の施設分布調查

•カーストの住み分け分布調查

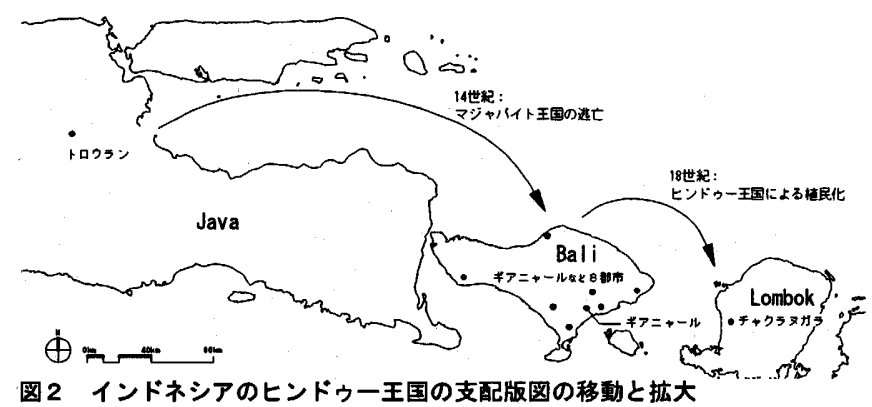

図 2 インドネシアのヒンドゥー王国の支配版図の移動と拡大
表1 ギアニャールとデサ・バンで行った閂き取り調查の内容とインフォーマント

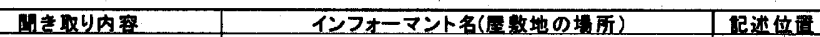

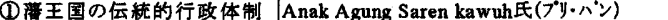

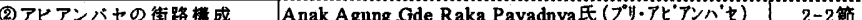

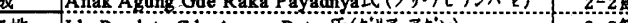

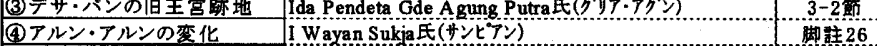

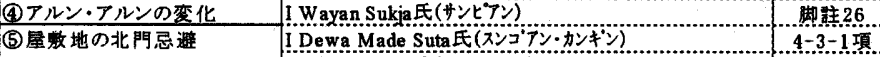
I Made Sliarsa

・バンジャールban jar ${ }^{7}$ と呼ばれるコミュニティ単位の境界調查 ・ギアニャールの 4 地区における屋敷地内の住棟構成の実測調查 ・表1に挙げた内容の聞き取り謂査 ${ }^{8}$

\section{1-2 既往の研究}

バリ岛に関して人類学からの研究は、「殷場国家ヌガラ」の概念を 提出したGeertz（1980）を筆頭に、近年ではバリ・ヒンドゥーの総 本山であるブサキBesakihの寺院群とその祭祀圈について綿密な考 察を行ったStuart-Fox(2002)など枚挙に暇がない。

建築·都市計画学からは、古バリ人の村落プランを復元したTan （1966）、伝統建築の保存問題を扱ったBudihardjo(1986)、伝統建築 における門の象幑性を考察したSaraswati (2002)、村落構成をモデル 化して示したGelebet (1978)、また本邦からはParimin (1986) と鳴海 (1993)による広箸な村落輠成の共同調查研究、軸線上に配置される 村落構成に着目した大谷 $(2000)$ 、古バリ人の村落について報告した 佐藤(1992)などがあるが、すべて村落あるいは伝統住居に関するも のである。

都市に関するものは、Nas（1995）による都市の交差点などに設置さ れる彫像の持つシンボリズムについての考察、Samadhi (2001)による バリの文化を崉まえた都市開発コンセプトの提案がある。また、上 述のStuart-Foxは、13分野を網羅したバリに関する文献リストを著 している。そのひとつの分野Social Sciencesの細分類Urban areas に、都市研究の文献が記されているが、ほとんどが都市開発整備の 計画・報告畵であり、都市構成を分析した学術的な研究は見られな いのが現状である。

\section{1-3 ギアニャールとデ・バンの摩史的関係と比较の視点}

ギアニャールの年代記によれば、その王家は初代王デワ・マンギ ス・クニンDewa Manggis Kuningが本貫村落バン（以下、「デサ・バ ン」10)に住み着いた。その後、二代目の王であるデワ・マンギス・ パハンPahangが、アビアンバセAbianbase、スロンゴSeronggo、ビ トラBiteraといった現在のギアニャール周辺の村落を興し、さらに 四代目の王であるデワ・マンギス・アピApiが、1771年にこれらの 村落の中心に、その結節点としてギアニャールを興した(図 4)。ギ アニャールは、グリア gria (家) +アニャールanyar (新しい) と いうバリ語をその名前の語源としている11。王族が住む新たな家を建 設して興した町ということである。

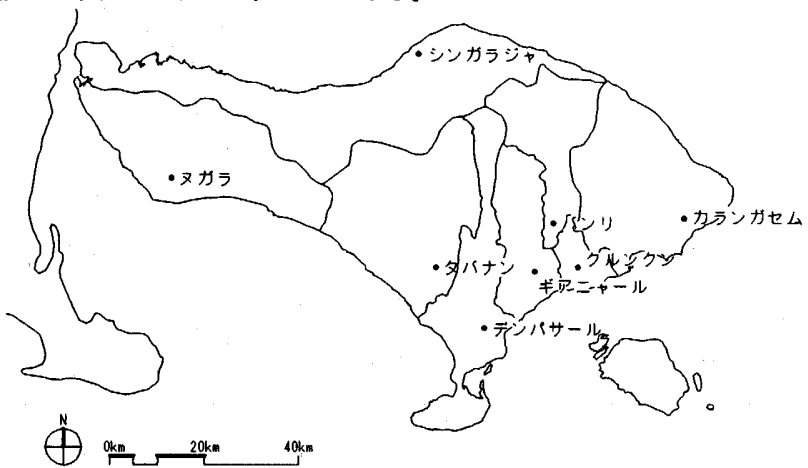

図3バリ岛の藩王国の支配版図と藩王国の王宫都市の位置 
バリ島においては、伝統的住居や屋教地は、村落と都市で基本的 に共通している ${ }^{12}$ 。このように集落 ${ }^{13}$ 構成する基本単位が共通して いる場合、村落棧成と都市構成の違いを見るには、路地、街路、宅 地といった都市組織の集合のしかたの違いが問題となる。この点に おいて、デサ・バンとギアニャールは、格好の比較考察を行う対象 となるのである。以下では、両者を比較しながら考察を行う。また 現在、ギアニャールとその南のアビアンバセは連続したビルトアッ プエリアなので、この両者は一体として扱う。

\section{2. 集落の基本構成と王宮}

\section{2-1王族階級の位とその伝統的行政版图}

ギアニャール藩王国の伝統的な行政体制は、後述する貴族階級の うち、特に王族によって担われてきた。その統治体系は、ラジャ raja（王）を頂点として、以下、位の高い順にパティpatih (大臣) ープンガワ pengawa (県知事) 一マンチャmanca（村長）の四段階か らなる。それぞれが位に応じた集落を世襲的に治めてきており、現 在もその子孫が各集落において、プリpuriと呼ばれる王宮に居住し 続けている。ラジャとパティは協同して、藩王国全体を治めた。そ の下のプンガワは、デサ・アビアンバセを治めてきた。デサ・バン、 デサ・スロンゴ、デサ・ビトラは、さらに村落のランクも一段階下 がり、マンチャが治めてきた14。

\section{2-2 中心街路と王宮の位置}

バリ島の村落は、山↔海の軸に沿った道に直線状に形成されるの が基本だが、村落が桩大すると、この軸と直行する道を持つように なり、村落は四辻を中心に形成されるようになる。鳴海(1993)は、 この変化を都市的な村落への移行状態とする15。デサ・バンも同様に 山↔海の軸と直行する(東西方向の)道を持ち、複数の四辻を持つ。

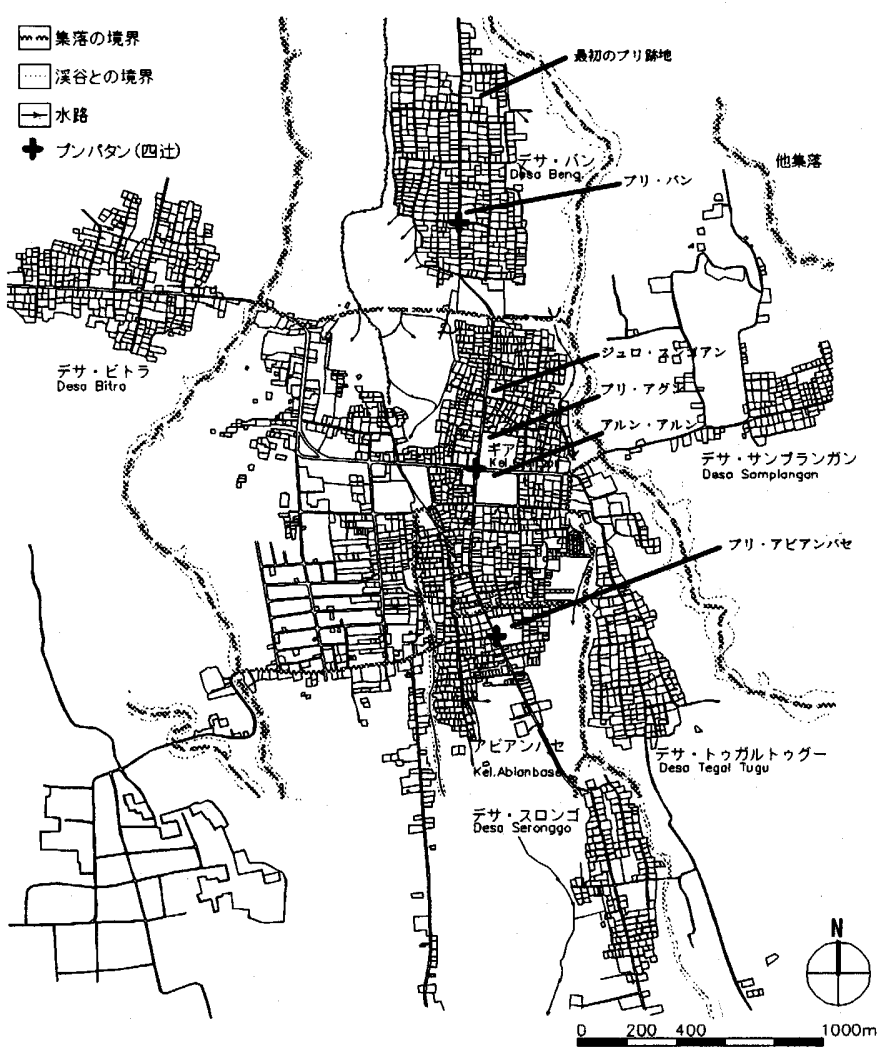

図4 デサ・バンとギアニャールおよび周辺村落の関係、 プンパタンとプリの位置
この四辻をバリ語では、プンパタンPempatanと呼ぶ16。ギアニャー ルは、その中心部に主要な四辻を都市の骨格として持つ。この四辻 は、プンパタン・アグンAgung（「高貴な四辻」の意味）と呼ばれる。 周辺には、王宮、アルン・アルンAlun-alunと呼ばれる広場等が位 置し都市の中心をかたちづくっている。デサ・バンの王宮、プリ・ バンは、プンパタンの北東角の敷地に位置している。同様にギア ニャールのプリ・アグンもプンパタン・アグンの北東角に位置する。 これは、ギアニャールにおいてナワサンガで最も神聖な区画である 北東角の方角に一致する。また、ギアニャールから、バリ島の聖山 でヒンドゥー教の世界中心山のメール山（須弥山）にあたるグヌン・ アグンGunung Agungを望む方角でもある。アビアンバセの王宮であ るプリ・アビアンバセは、南北道路に東西道路が西から交差する三 差路の突き当たりに位置する。聞き取りによれば、形態的には三差 路であるが、人々はこの三差路を習慣的にプンパタンと呼んでいる という。プリ・アビアンバセも三差路から見ると、北東側にその中 心がある17。つまり、概念的には、プリが四辻の北東角に建つこと は、人々によって共有されていると考えてよい。さらにギアニャー ルでは、プリ・アグンから北側に、ジュロ・スンゴアンJero Sengguanと呼ばれる王族の末裔の屋敷地があるが、これもプンパタ ンの北東角にある ${ }^{18}$ 。

以上のように、集落の中心骨格にプンパタンを持ち、その東北 角にプリあるいはジュロがあることは、全ての集落に共通の特徵 である。

\section{3. カーストの住み分け}

3-1 バリ島におけるカースト

バリ島には、インドと同様の身分制度があり、カスタkastaと呼 ばれる。インドにおけるヴァルナ制度は、身分の高い順にブラーマ ン(僧侣階級)、クシャトリヤ(貴族階級)、ヴァイシャ(商人階 級)、シュードラ(奴隷階級)の四階級からなるが、バリ島のカスタ もほぼ同様の身分階級名で呼ばれる。上からブラーフマナbrahmana、 サトリアsatria、ウェシアwesia、スードラsudra（あるいはジャバ jaba $\left.{ }^{19}\right)$ の四階級である。ただしスードラという呼称は通常避けら れ、その代わりにバリ・ビアサBali biasa (「一般バリ人」の意味) が用いられる。ブラーフマナ、サトリア、ウェシアの3カーストは、 上位カーストとしてまとめられトリワンサTriwangsaと呼ばれる。 これも上位 3 ヴァルナがインドでも再生族と呼ばれるのと対応する。 また、バリ島に特有の身分階層として、パンデPandeと呼ばれる階 層がある。これは特にその瞕能と結びついた階層であり、世襲的に 鍛冶屋を生業とし、クリスkerisと呼ばれる正装時に佩用される短 剣を鍛造してきた人々である。

尚、カーストの住み分け分布調查は、バリ島に特有のカーストに 応じた命名方法を頼りに、居住者の名前からカーストの特定を行っ た。デサ・バンとギアニャールについては、直接に居住者から名前 の聞き取りを行ったが、アビアンバセについては、基本的に屋敷地 に表札が掲げられており、これをもとにカーストの特定を行った。

\section{3-2 デサ・バンにおけるカーストの住み分け}

図 5 (上側)にデサ・バンにおけるカーストの住み分けを屋敷地 ごとに示し、同時に街区を基本として、便宜的に東西方向最大 4 区 画、南北方向最大 5 区画に分割して番号をふり、その区画ごとに各 


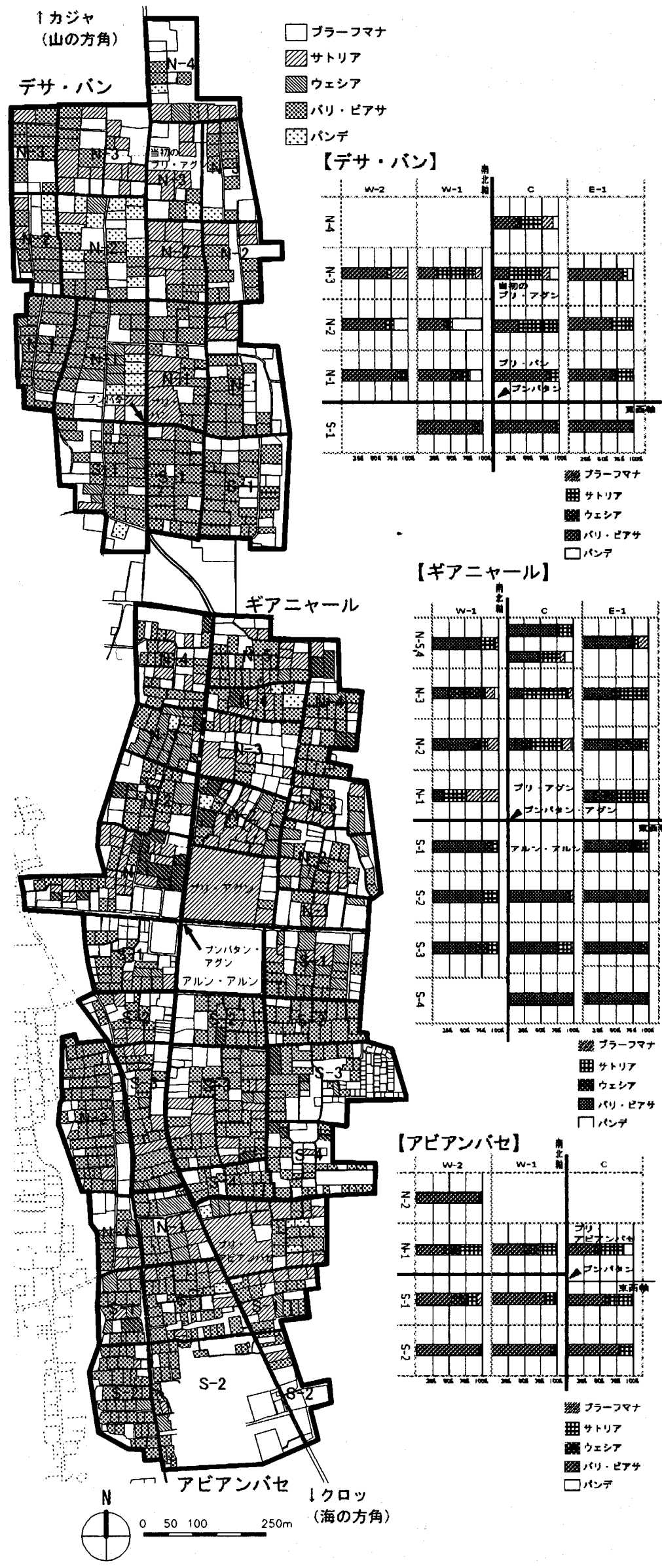

図 5 デサ・バン、ギアニャール、アビアンバセにおける カーストの住み分けと分布割合
カーストの占める割合を示した。

デサ・バンは地形的には南から北に向けて（図 5 で下か ら上へ)高くなっていく土地にある。基本的にトリワンサ と呼ばれる上位 3 カーストが、地形的にはより高い北半分 $(\mathrm{N}-4, \mathrm{~N}-3, \mathrm{~N}-2$ 行) に集中し、バリ・ビアサが南半分 (N$1, \mathrm{~S}-1$ 行)に集中している20。また、パンデの屋敷地は、プ リの西側と村落の北半分に住んでいることから、その階級 はトリワンサに準じるものであることが分かる。

トリワンサのうち最も身分が高いブラーフマナの屋數地 は、村落の北端に集中している。ブラーフマナの屋敷地 は、一般にグリアと呼ばれる。その中でもプダンダ pedanda と呼ばれるヒンドゥー教の最高司祭が居住する格 式の高い家系の住む屋敷地は、グリア・アグンと呼ばれ、 デサ・バンでは図 5 の N-3 行 W-1 列にある21。

聞き取りによれば、村落を南北に貫通する幹線道路を挟 んで、グリア・アグンの東隣の空地 (N-3 行 C 列) は、王宫 がギアニャールに移転した跡地だというる。ブラーフマナ、 サトリアの階級のうちでも、その代表格であるプダンダと ラジャが、村落の北端に屋贱地を構えていたのである。

以上より、デサ・バンでは、山海の軸である南北方向 に沿って、身分が高いほど山に近い北側に住むというかた ちでカーストが住み分けられていることが分かる。つまり、 地形、象街的方位、カーストの分布が、それぞれ対応しな がら直線状にヒエラルキーを形成しているのである。

3-3 ギアニャールにおけるカーストの住み分け

図 5 (中程以下)にギアニャールにおけるカーストの住 み分けを屋敷地ごとに示した。デサ・バンと同様に、東西 方向最大 3 区画、南北方向最大 9 区画に分割して各カース トの占める割合を示した。

ブラーフマナは、N-1行W-1列、ブリ・アグンの西隣に最 も集中している。二つの家系から成るこのブラーフマナの

屋数地のコンプレックスは、グリア・カワンkawuhanと呼ば れる23。プンパタン・アグンを形成する道路を挟んで、東側 にプリ・アグン、西側にグリア・カワンが配置されるかた ちは、デサ・バンと同様である。また、他のブラーフマナ の屋敷地は単にグリアと呼ばれる。これらは、一部の例外 はあるが、基本的にプンパタン・アグンの北側、つまりギ アニャールの北半分に分布している。

サトリアは、 $\mathrm{N}-2$ 行 $C$ 列、 $\mathrm{N}-3$ 行 C列、 $\mathrm{N}-1$ 行 E-1列といっ たブリ・アグンに近い場所で高い割合を示している。ギア ニャール全体を見た場合には、やはり、ブラーフマナの場 合と同様にプンパタン・アグンの南側街区 (S-1行) より北 に集中している。

ウェシアもサトリアとともに、S-1行より北に分布してい る。しかし、プリ・アグンがあるC列でサトリアの割合が高 いのに対し、その両脇のE-1列、W-1列でウェシアの割合が 高い。中心より北側に分布しつつも、ウェシアはサトリア より低い身分階層として、その外側に居住している様子が 伺える。

バリ・ビアサは、バリ島全体の人口の約 9 割を占めるこ 
表 2 バリ島における惯習法上の土地所有制度（Stuart-Fox(2002)による）

\begin{tabular}{|c|c|c|c|c|c|}
\hline 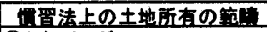 & 芹有䖭 & 用造 & 责 & 盖溇 & 税金 \\
\hline (タタナ・カスキハン & 私有. & 㻃地:突地 & 可 & 基本的结 & \\
\hline (2)力ラン・デサ & 杜落 & 宅地。 & 不司 & 寺腙 & \\
\hline (3)タナ・アヤハン & 私直 & 㗔地 & 可 & 寺院:村落溔礼熱行 & $=$ \\
\hline (4タナ・デサ & 村落 & 走旨鹿地 & 不可 & trt & $=$ \\
\hline (5)ナ・ラパ・プラ & 寺陪 & 雪地 & Phts & 院人O黄納 & fil \\
\hline (6)タナ・ドゥルエ・プラ & 寺院 & 溇地 & されない & 寺院への貫納 & Tan \\
\hline
\end{tabular}

ともあり、市域全体に分布しているが、その分布特徴には以下の 二点が指摘できる。一点目は、ひとつの街区（S-1 行 E-1 列）を除 いて、プンパタン・アグンの南側では全ての街区で 7割を超えて いることである。さらにその半分の街区で 9 割を超えていること から、市域南半分は、基本的にバリ・ビアサの居住区と考えてよ い。二点目は、プンパタン・アグンの北側に分布するバリ・ビア サの割合は、市域の北端街区（N-4, N-5 行）や東西の端の街区（E1 行，W-1行）というように、周辺ほど割合が高くなる傾向がある ことである。

パンデもデサ・バンの場合と同様に少数だが市域北側に分布する。 以上から、ギアニャールにおけるカースト分布は、基本的に市域 北半分にトリワンサ、南半分にバリ・ビアサというデサ・バンの場 合と同じ山↔海の軸線に沿った分布特徴を示す一方で、特に市域中 心のプンパタン・アグンに面してグリア・カワンとプリ・アグンが あること、市域北半分においても周辺部ほどバリ・ビアサの割合が 高まることを考えれば、中心により高い身分階層が、周辺ほど低い 身分階層が居住する傾向がある。つまり、山↔海の直線状の分布と 中心↔周辺の放射状の分布が重なりあっていると考えられる。

\section{4. 街区構成と宅地割り}

\section{4-1 バリ島における慣漗的土地所有制度}

街区構成と宅地割りについて述べる前に、それらと深く関保する バリ島の土地所有制度について、既往文献をもとに触れたい。

Stuart-Fox (2002)によれば、バリ島の寺院の総本山であるブサ キ寺院のある西カランガセム地方では、表 2 に示したように(1)夕 ナ・カスギハンTanah kasugihan、(2)カラン・デサKarang desa、 (3)タナ・アヤハンTanah ayahan、(4)タナ・デサTanah desa、(5)夕 ナ・ラバ・プラ Tanah laba pura、(6)タナ・ドゥルエ・プラ Tanah druwe pura、といった慣習法（アダットadat）に基づく6 種類の 土地所有制度があるという。表 2 の所有者、用途、売買、義務の各 項目は慣習法上の規定であり、税金だけが公的な法律による項目 である。(5)と6は、慣習法上の規定は同じであるが、政府に税金 を払うか否かという点のみ異なる24。

以下で触れるギアニャールの事例に関連して触れておきたいのは 用途が宅地の場合である。私有であれば(1)、村落の共有であれば(2) である。(1)は売買が可能で、土地所有による義務もないのに対して、 (2)は売買ができず寺院の儀礼執行の義務がある。ギアニャールの宅 地の土地所有は、(2)のカラン・デサである。上述の場合と同様に、 土地は売實することはできないという。また、カラン・デサの区画 数は基本的に固定されており、部分的に区分けして売ることもでき ない。ギアニャールのビルトアップエリアを示した最も古い資料は、 オランダ植民地政府が 1924〜25年に作成した縮尺5万分の 1 の地図 25であるが、その広がりは70年以上を経てほぼ同じである26。ギア ニャールの宅地割りは、少なくとも近代において大きな変化を受け ておらず、ある程度、古いものであることは確かである。
また、土地が壳買できないことは、その屋數地に住む人々も固 定されてきたことを示す。上述のカースト分布もギアニャール成 立当初から大きく変わっていない可能性が高い27。

\section{4-2デサ・バンの街区における宅地割り}

図 6 (上側)にデサ・バンにおける宅地割りを街区ごとに分類し て示した。ここでいう街区とは、四方を道で区切られた屋數地の集 合を示す。宅地割りパターンには、i )南北軸背割り型、ii )不規則 型、 iii) 東西軸背割り型、iv)南北軸一列型、v) 東西軸一列型の 5 つ が見られる28。

圧倒的に多いのは、i ) 南北軸背割り型である29。ii ) 不規則型をと るのは、後にギアニャールへ移ることになる最初のプリ・アグンが あった街区のみである。このプリ・アグン跡は、他の街区と比較し て東西方向の距離が長いため街区のスケールが大きいからである。 王宮故の例外的な街区と考えられる。iii) 東西軸背割り型、iv)南北 軸一列型、v)東西軸一列型は、村落の境界に見られるだけである。 4-3 ギアニャールの街区における宅地割り

ギアニャールでは、プリ・アグンやその南側のアルン・アルンの 街区に沿って主要な街路が通り、周辺の街区が形成されている。デ サ・バンにおける街区と比較すると、東西方向に長いのが特徴であ る。このように村落であるデサ・バンには見られない、中心施設の ある街区の大きさに沿った、いわば、「都市型街区」と呼べるような 方形に近い街区が出現している。

宅地割りパターンは、デサ・バンで見られた 5 類型と基本的には 同じである。しかし、デサ・バンでは i )南北軸背割り型が支配的で あったのに対し、ギアニャールでは、様々な宅地割りがモザイク状 に混在している(図6 中程以下)。図 7 にギアニャールで見られる宅 地割りパターンを図式化して示した。

以下では、異なる宅地割りパターンを持つ街区の事例を取り上げ、 その都市組織の構成を検討する。尚、iv)南北一列型については、デ サ・バンと同様に集落の東西の端部に見られ、特に都市型街区の影 響を受けていないため事例検討を行わない。

4-3-1 不規則型: スンゴアン・カンギンSengguan Kangin地区 ${ }^{30}$ (図 8)

プリ・アグンやアルン・アルンに隣接する街区では、不規則型が 多く見られる。スンゴアン・カンギン地区は、プリ・アグンの北側 に隣接する街区である。街区内部に表通りからは直接入ることので きない宅地が多く存在する。このため街区内部には多くの路地が存 在する。街区東側、南側、西側から内部へ入る路地は、数が少なく 比較的短いものが多い。一方で、目立つのは北側から街区内部に入 る路地である。また、図8には、屋教地に入る門の位置を示したが ( $\Delta$ 印)、街区北側の街路に面寸る屋敷地は、街路に向かって直接的 に門を設けることはせず、一度路地に入ってから屋敷地に入る。こ の点も、その他の方角の街路に面する屋敷地が、街路に面して直接 に門を持つのと大きく異なる。

聞き取りによれば、屋敷地の北口に門があると、居住者は屋敷地 から外に出るときに聖山であるグヌン・アグンの方向を踏みつける ことになり、非常に縁起が悪いという。ナワサンガの理想型では、 バリ島の南部では本来、門は屋敷地西側の南端部、つまり最も世俗 的な位置に設けられる。実際、北側に門を持つ屋敷地で重病人が出 るなどした後、門を西側に付け替えた例もあるという。Saraswati 


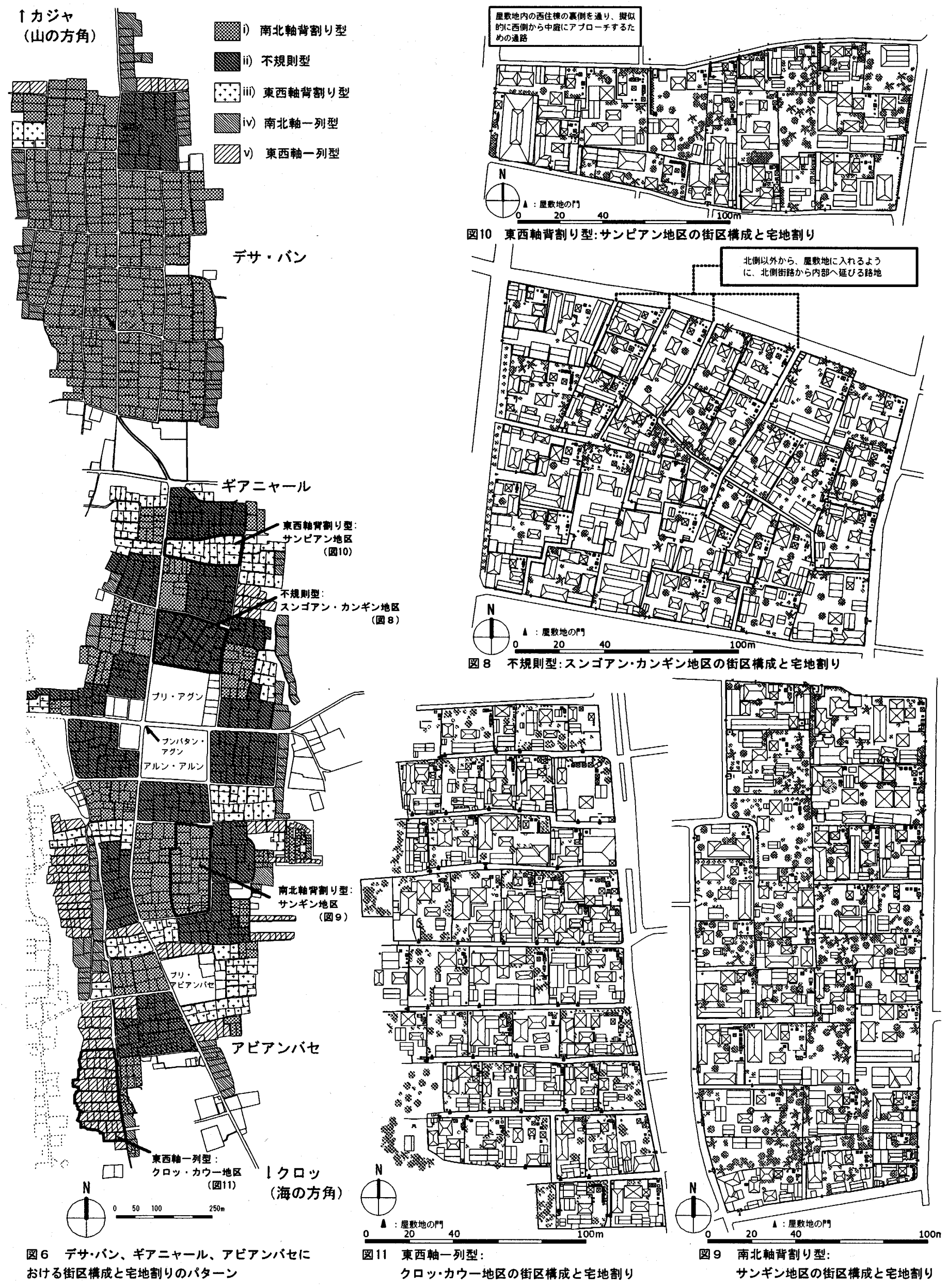




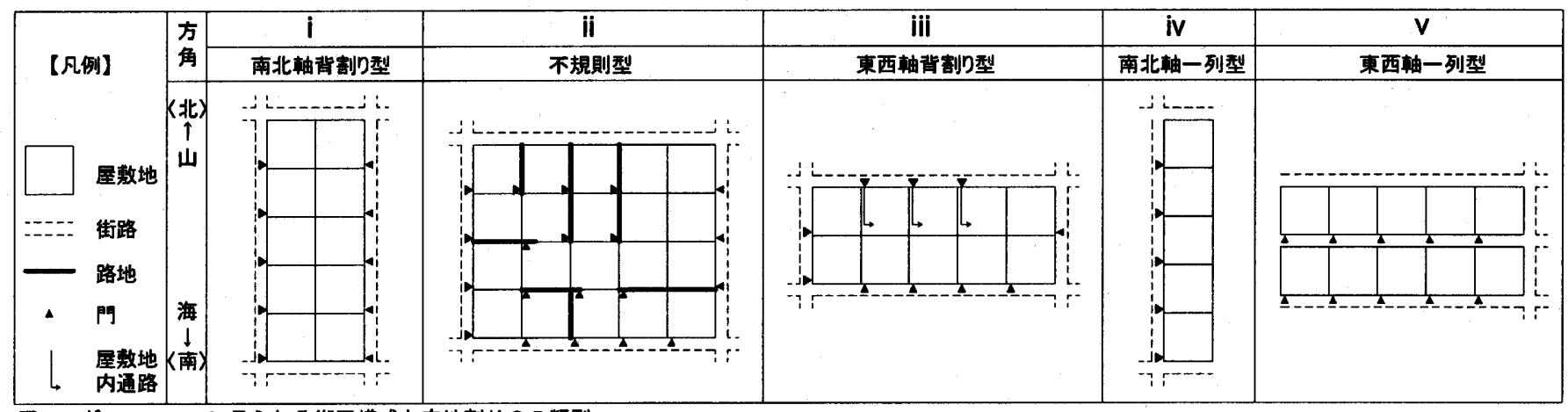

図7 ギアニャールに見られる街区構成と宅地割りの5 類型

(2002)は、バリの屋敷地の門は、正確には入口というより、屋敷地 からの出口の性格を持ち、人体に例えれば、北東角区画の屋敷神 (サ ンガ Sanggah)が頭とするなら、出口である門は、いわば「排泄口」 にあたるという ${ }^{31}$ 。以上の理由で、バリ島の屋敷地では、聖山に向 かって門を設けることは忌避されているのである。

スンゴアン・カンギン地区で、北側街路に面して門を設けず、北 側街路から街区内部に向かう多くの路地を持つのはそのためである。

また、北門を回避する理由として、カースト分布との対応を指摘 しておきたい。市域北側に上位カーストが住むため、その向きに出 る門を設けないという可能性がある。随唐長安城で、宮城・皇城の 南側の街区が十字街でなく横街のみを持つ（左右民原）のと同様に、 身分の差による社会関保が投影されているとも解釈できる。

\section{4-3-2 南北軸背割り型：サンギンSanggin 地区（図 9）}

南北背割り型の宅地割りパターンは、デサ・バンに見られる基本 型である。これは、上述の北側の門の忌避を考えた場合、東西のど ちらかに必ず門を設けることが可能な宅地割りパターンとして、理 にかなったものであることが分かる。

ギアニャールでも同様な宅地割りパターンが散見されるが、都市 型街区を考慮した場合に特徽的なのは、南北軸背割り型が、街区を 南北軸に沿って短冊型に二分した片方として成立している場合であ る。アルン・アルンから 2 ブロック下のサンギン地区がその事例で ある。サンギン地区の東西幅は、屋敷地のスケールに対して、依然 として単純な南北背割り型街区より長い奥行きを持つため、街区内 部への路地がいくつか見られる。しかし、当該都市型街区全体が、 真ん中の路地によって短冊型に二分されているのは、南北背割り型 に準ずる宅地割りパターンを実現するためと考えてよい。

4-3-3 東西軸背割り型：サンピアンSampi ang 地区（図 10）

東西軸背割り型は、ギアニャールのやや周辺部に見られる。サン ピアン地区は、スンゴアン・カンギン地区からさらに 2 ブロック上 に位置する。同様に背割り型でも、東西軸背割り型の場合は、北側 列の屋敷地は街区北側に向かって門を設けるより手だてがないよう に思われる。確かにサンピアン地区の北側の屋敷地列では街区北側 の街路に面して門を設けている。

しかし、門から屋敷地内に入ると図10内の矢印で示したように、 バレ・ダウーbale dawuh（より格式の高いものはロジlogi）と呼ば れる西住棟の背面が通路となっており、その後東に折れ曲がって中 庭に入る動線になっている。折れ曲がりの突き当たりには、プリン ギー pelinggihと呼ばれる祠が立つ場合が多い。これは、通常門のす ぐ内側に立ち屋敷地入口を守護するものである。つまり、街区北側 の屋敷地では、屋敷地内の西端に沿って、さらに通路を設けること
によって、プリンギーの立つ地点から擬似的に西側より屋敷地に 入るように見せかけているのである。

4-3-4 東西軸一列型 : クロッ・カウーKelod Kawuh地区 (図11)

東西軸一列型は、市域の周辺部に見られる。クロッ・カウー地区 は、アビアンバセの南西端にある。東西方向に連続した屋教地列が 複数ならんだ構成をとるが、各屋敷地列の間には全て路地が通って いる。これは全ての屋敷地に南から入れるようにするためである。

\section{5. まとめ}

本稿では、バリ島のギアニャールとその出自の村落デサ・バンを 比較しながら、バリ島におけるヒンドゥー都市の構成について考察 を行った。以下にまとめる知見は、あくまで本稿で扱った事例であ るデサ・バンとギアニャールの相違に関するものであるが、今後、 ヒンドゥー文化の影響を受けたバリ島の村落と都市を比較する重要 な視点と考える。

(1)王宮であるプリの位置は、王族内の位の上下に関わらず、プンパ タンと呼ばれる四辻の北東角にある。この方位は、ナワサンガに基 ぶく最も神聖な方位と一致する。これは、デサ・バンとギアニャー ルに共通している。

(2)カーストの住み分けは、デサ・バンでは、山↔海の方向である南 北軸に沿って、北側に上位カースト、南側に下位カーストといった ように、象徴的体系、地形の高低、カーストが対応しながら直線状 に住み分けがなされている。ギアニャールでも同じ傾向が見られる が、一方で市域中央のプンパタン・アグンやプリ・アグンを中心に 上位カーストが集中し、周辺に行くほど下位カーストの割合が高く なるという同心円状の住み分けが見られる。ギアニャールにおいて は、中心@周辺の空間ヒエラルキーが生まれている。

(3)デサ・バンの街区構成は、基本的に南北軸背割り型の宅地構成か らなる。バリ島において忌避される屋敷地北側に門を設けることを 回避する上で、理にかなった街区構成と宅地割りパターンをとって いると考えられる。

(4)ギアニャールでは、デサ・バンと比べて方形に近い都市型街区が 成立している。このため南北軸背割り型を中心としたデサ・バンと 同じ宅地割りを持つことができず、南北軸背割り型、不規則型、東 西軸背割り型、南北軸一列型、東西軸一列型の 5 類型の宅地割りが 混在している。特に不規則型は市域中心部に、南北軸一列型と東西 軸一列型は市域周辺部に見られる傾向がある。

南北軸背割り型は、各屋敷地が北側に門を持たなくてもよい宅地 割りである。不規則型の場合、街区北側に面する屋敷地でも、屋 敷地内には路地を通って東側または西側から入る。東西軸背割り 
型の場合、街区北側に面する屋敷地は、屋敷地内に通路を設け擬似 的に西側から屋敷地に入るように見せかけている。南北軸一列型は 基本的に南北軸背割り型の半分として東西どちらか側に門を持つ。 東西軸一列型は街区の南側に必ず道と門を持つ。以上の宅地割りの 類型は全て、ナワサンガに基づいて聖山の方向である屋敷地北側に 門を持っことを忌避することによって成立したことが説明できる。 (5) 18 世紀にロンボク島に建設されたチャクラヌガラ（図 1) は、純 粋な南北軸背割り型の街区の集合からなる。これは植民都市として 新たに計画されたチャクラヌガラが、北側に門を持つ屋敨地をつく らないための理想的な都市形馝を基底として建設されたためである と考えられる。

\section{参考文献}

[1] 布野修司, 脇田祥尚, 青井哲人, 牧紀男:チャクラヌカライインドネシ ア・ロンボク島) の街区楼成ーチャクラヌガラの空間構成に関する研究 そ の1, 日本建築学会計画系諭女集, 第491号, pp. 135-140, 1997.1

[2] 布野修司, 脇田祥尚, 牧紀男, 青井哲人, 山本直彦: チャクラヌガラ (インドネシア・ロンボク島)の祭祀組織と住民組織ーチャクラヌガラの空間 構成に関する研究その 2 , 日本建策学会計画系略文集, 第503昌, pp. 151$156,1998.1$

[3] 布野修司, 脇田祥尚, 牧紀男, 青井哲人, 山本直彦: チャクラヌガラ (インドネシア・ロンボク岛)における楼み分けの特性ーチャクラヌガラの空 間粠成に関する研究その 3 , 日本建案学会計画系馀文集, 第 510 号, pp. $185-190,1998.8$

[4] 石井米雄監修,『インドネシアの事典』, 同朋舍出版, 1991

[5] ミグル・コバルビアス (関本紀关子訳)，『バリ岛』，平凡社，1936

[6]クリフォード・キアツ (小泉润二訳)，『ヌカラ19世紀バリの地場国 家』，みすず房， 1980

[7] Stuart-Fox, D., "Pura Besakih", KITLV pr., Leiden, 2002

[8] Tan, R. Y. D., 'Description and Comparative Analysis of the Domestic Architecture of South Bali', M.A. thesis, Yale Univ., 1966

[9] Budihardjo, E., "Architectural Conservation in Bali", Gadjah mada University Press, 1986

[10] Oka Saraswati, A. A. Ayu, "Pamesuan", Universitas Udayana, 2002

[11] Gelebet, I. N., 'Arsitektur Tradisional Bali', 1978

[12] Parimin, A. P., 'Fundamental Study on Spatial Formation of Island Village: Environmental Hierarchy of Sacred-profane concept in Bali', 大阪大学学位睮 文, 1986

[13]大谷姟，「軸の集住による生活空間の研究ーインドネシア、バリ島を中 心として一」，佐贺大学学位綸女, 2000年

[14]佐藤浩司，殿合に住むロンボク岛、バリ島の住空間」、『季刊民族 学62』国立民族学博物馆, 1992秋易, pp. 86-99

[15] Nas, P. J. M., 'The image of Denpasar: About urban symbolism between tradition and tourism' in "Issues in Urban Development", CNWS, Leiden, 1995

[16] Samadhi, T. N., 'Cultural Based Town Form Determinants and the Development of Balinese Urban Design Concepts', The 1st World Planning Schools Congress, 2001

[17] Stuart-Fox, D., "Bibliography of Bali: publications from 1920-1 990", KITLV Pr., Leiden, 1992

[18] 鴞海邦碩他、『神々と生きる村 王宫の都市ーバリとジャワの集住の橉 造一』, 学芸出版社, 1993

[19] Mahaudiana, "Babad Manggis Gianjar", A.A.Gde Thaman, 1968

[20] 吉田禎吾,『バリ島民』，弘文堂，1992

\section{脚柱}

1 參考文献 $[1] \sim[3]$

2 本稿では、バリ岛の王国は清王国とし、ジャワ島のヒンドゥーまたはイスラ 一ム王国は単に王国と記述する。藩王国とはイギリス統治下のインドの土着 王国を指し示寸用㕶であるが、バリの場合も同様に群雄割挆の状態が見られ る。一方でジャワの王国はジャワ全体を単一で支配しており状况が異なる。

3 ジャワの最後にして最大の古代王国。1293年にシンガサリ朝のウィジャヤ により建国される。その衰退時期は15世紀初頭から15世紀後半など諸説あ る。(参考文献 [4], pp. 403-405)

4 1365年成立。同王国の宫廷詩人プラパンチャが釉ったもの。1894年のオラ ンダのロンボク島遠征の際にチャクラヌガラから発見され、13〜14世紀の ジャワ社会を理解するための基本資料とされる(参考文献[4]，pp. 302$303)$ 。

5 参考文献[5], p. 78

6 執筆者に加え、以下が調查者として参加。宇都宫崇行、鈴木星䅹、高㛢俊 也 (以上、京大) 下川晃生、辻宗彦、長谷川豪 (以上、立命館)。

7 バンジャールは、慣習的に成立した伝統的な地縁コミュニティであるバン ジャール・アダットbanjar adatと近代化の中で行政区画によって線引き された単位としてのバンジャール・ディナスdinasが存在する。

8 表lに举げた開き取り跱查は、筆頭著者が直接にインフォーマントにイン ドネシア語で行った。カースト、コミュニティ単位の聞き取りは、筆頭著 者が簡単なインドネシア颜による調查指示を行い全調查メンバーで行った。 9 参考文献 [5]〜 [18]

$10 「 テ ゙ サ$ desa」は、インドネシア語、バリ語で、「村」を示す。

11 参考文献[19], pp. 7-29

12 一般にバリ岛の伝統的住居は、バリ・アガと呼ばれるヒンドゥー文化到来 以前の古バリ人の村落住居と、バリ・マジャパヒトと呼ばれるヒンドゥー 化後の住居に大別される。ここで村落と都市で共通していると述べるのは、 バリ・マジャパヒトを指している。

13 本稿では、「集落」=settlement の訳語として使用している。つまり、 集落は、村落、都市の両者を包含する概念として用いている。

14 大臣、県知事、村長は、そのヒエラルキーを表すための便宜的な日本語訳 である。現在の行政区分としては、バン、スロンゴ、ビトラは、村落部を 示すデサであるが、ギアニャールとアビアンバセは、都市部の行政単位と してインドネシアで一般的に使われるクルラハンkelurahanに分類されて いる。

15 产考文献 $[18]$ p. 70-72

16 インドネシア語のperempatan (四计)にあたる。

17 プリ・アビアンバセは、山側(北) のプリ・カレランkaleran (北プリの 意味、カレランは、バリ語で「山へ」を示すカジャの雅語) と海側(南) のプリ・クロダンkelodanから成る。当然、山側の方が格式が高い。

18 「ジュロ」とは、王族の子孫の系譜から傍流として外れ、プリの外に居を 㭗えた貴族の末裔の屋数地を指す。スンゴアンは、ギアニャールのバンジ ヤールのひとつの名前である。ジュロは、「内」の意味であり、傍轧である が元来は、王族の内に含まれることを示していると考えられる。

19 ジャバはバリ語で「外」の意味である。つまり外部の人の意味である。

20 カーストの割合を示すグラフは、プリの位㼂する四辻より、北側を $\mathrm{N}$ 、南 側を Sとし南北方向(行) を記述する。若い番号ほどプリに近い。またプ リの位圆する絆列(列)をC (Center)とし、東側を E、西側をWとする。

21 こうした格式の高い屋教地内では、住梀も格式の高いものが見られる。通 常、ブラフマやサトリアの秶教地内の北側に建つ母屋はグドンgedong と呼 ばれ、バリ・ビアサの屋晋地の母屋がムテンmetenと呼ばれるのと異なる。 グリア・アグンなどでは、さらに格式の高いグドンが見られ、グドン・グ ヌン・ラタgedong gunung rataと呼ばれる。クドンのテラスが二段になっ ているものがこう呼ばれる。グヌンは山、ラタは平地の意味で、前者は屋 根、後者はテラスを示している。デサ・バンのグリア・アクンンの家艮でキ アニャールの最高司祭ブダンダであるIda Pendeta Gde Agung Putra氏に よれば、段階状のテラスから徐々に上がって鼠終的に屋根にいたる住居の かたちが、グヌン・アグンを中心としたバリ岛全体をシンボライズしたも のだという。

22 吉田 (1992) p. 53によれば、一般に現在でも王（その子柇）の住む屋制 地である宫廷プリは西に面し、ブラーファナの住む屋数グリアは東に面し ているという。東西の方角に関しては、象徽的に東 (日の出) が西(日の 入り)に传れている。法的権威は宗教的権威に従い、王は特にプダンダに 敬意を払うため、このような配閪関保になっているのである。

23 カワンは、カウー(「西」の意味) の派生研であり、グリア・カワンは、 「西のグリア」の意味である。

24 表2は、考文献[7] pp. 40-46による。一印は同文献に記述が無い項目。 25 オランダ植民地政府地理局 (Topografischen Diesnt) が1920年代に夷 測・作成発行したもの。バリ島全体を22葉によってカバーしている。その うち当該葉の番号は、Blad 105D. (Alg. No. XLIV-62D)。尚、本稿では、 日本軍がリプリントしたものを参照した。

26 アルン・アルン内に存在した屋敷地は、第二次大戦後、図 5 でギアニャー ルのS-2, S-3行E-1列に移動させられたという。

27 カラン・デサの場合、血縁が絶えて相絖者がいなくなれば、理䃋的には居 住権は村落内で諘渡される。しかし、Stuart-Fox (2002) も指摘するように、 バリ社会においては前近代から引き緒き拁大家族で居住してきたので、家 系が断絶し居住者が入れ替わる現象は希なはずである(参考文献[7]， p. 43)。

28 背割りの宅地を持つ街区の中には、路地から引き込まれる街区内部の宅地 が存在し、部分的に 3 列になる街区があるが、これらも街区の權成は背割 りが基本となっているので、特に区別を行っていない。この点については 次節のギアニャールの場合も同様である。

29 本稿では結論部分で、この理由が、北門回避に起因することを指摘している が、その議諭は、4-2 のデサ・バンに関する部分でなく、後述する4-3-2 の ギアニャールの南北軸背割り型について触れる中で行っている。現地調查は、 最初にデサ・バン、次にギアニャールの順に行った。しかし、規則正しいデ サ・バンの宅地割りからは、その理由が分からず、様々な宅地割りが混在する ギアニャールで、何か特異点が無いかを検討した結果、北側に門を設けられる 余地があるのに北門が無い事実から、北門回避とその理由が明らかになったか らである。そこから逆にデサ・バンの宅地割りがひとつの理想型を実現している という見方に達した。本稿で、デサ・バンの宅地割りについて敢えて、事実と 理由を異なる節で説明しているのは、以上の現地謂查と思考のプロセスに沿っ たためである。

30 これらの地区名は、その街区が属するバンジャールの名前である。

31 参考文献 $[10]$, pp. 46-73

(2004年10月 8 日原稿受理, 2005 年 3 月 14 日採用決定) 